\title{
The Reflections of New Public Management on Local Government Laws in Turkey
}

\author{
Assistant Professor Dr. Zuhal Önez Çetin \\ Uşak University, Public Administration Department, Head of the Local Government Studies \\ zuhal.cetin@usak.edu.tr, zuhalonez@gmail.com
}

\author{
Doi:10.5901/mjss.2015.v6n4p36
}

\section{Abstract}

By the 1980s onwards, the management of public sector has witnessed a significant transformation and a new paradigm came out with the name of the New Public Management (NPM), as a challenge to the classical public administration. At that framework, Turkey has also felt the impact of that new paradigm at the administrative system. The first objective of the article is examining the emergence of NPM at the global planet. In that context, the key themes, initiatives, and principles of NPM have been put forth in detail. The second objective of the article is searching the emergence of the new paradigm of NPM in Turkey. The third objective is examining the general justifications of four Local Government Laws such as Special Provincial Administration Law No. 5302, Municipality Law No. 5393, Metropolitan Municipality Law No. 5216 and lastly, Law No. 6360 on 'The Establishment of Fourteen Metropolitan Municipalities and Twenty-seven Districts and Amendments at Certain Law and Decree Laws'. The general justifications of those Laws are analysed with the method of content analysis for the evaluation of NPM approach's key themes, principles, and components at the reference Laws. Lastly, it is seen that most of the principles of NPM are expressed at the general justifications of that related Laws such as decentralization, performance management, flexibility, effectiveness, efficiency, subsidiarity, participation, service quality, competitive and enterprising government, accountability, and transparency.

Keywords: New Public Management, Local Government Laws, General Justifications

\section{Introduction}

By the 1980s onwards, the management of public sector has witnessed a significant transformation in many developed countries at the global planet (Özer, 2012: 202). This case cannot be viewed as a simple change, but it has been evaluated as a paradigm shift in the classical public administration. Therefore, NPA, as a new paradigm came out as a challenge to the classical public administration and its limited nature, culture, and principles (Ömürgönülşen, 1997: 517). Likewise, Sarker and Pathak (2000: 57) expressed that NPM is different from the traditional public administration and put forward the view that traditional public administration at the global planet failed to reach the perception of the environmental forces that the governments encountered in the last twenty years that NPM came out as a response to those related forces. At the other side, Promberger and Rauskala (2003: 1) clarified that by the 1980s onwards, the study of public sector faced with a paradigm shift from the principles of public administration (Weberian model of public administration) to those of public management. By that paradigm shift, the public sector started to have more common peculiarities with the private sector. At that point, Dunleavy and Hood (1994: 9) put forth that paradigm shift with those clarifications;

- Budgets being transparent in accounting terms, with costs attributed to outputs not inputs, and outputs being measured by performance indicators.

- Viewing organisations as a chain of low-trust principal/agent relationships and a network of contracts linking incentives to performance (rather than long term relational commitments or trustee-beneficiary ones).

- Disaggregating separable functions into quasi-contractual or quasi-market forms, particularly by introducing purchaser/provider distinctions.

- Opening up provider roles to competition between agencies or between public agencies, firms and not-forprofit bodies.

- Deconcentrating provider roles to the minimum-feasible sized agency, allowing users more scope for 'exit' from one provider to another, rather than relying on 'voice' options to influence how public service provision affects them.

In this regard, the new values of the public sector can be listed as follows; giving priority to the market rather than hierarchical bureaucracy, focusing on responsibility towards customers, concentrating on the results rather than the 
processes, overemphasizing on business management rather than public administration, concentrating on economy, efficiency, and effectiveness (Ömürgönülşen, 1997: 531). As it was seen from the above-listed features, NPM approach take its source from the fundamental values of market mechanisms such as customer orientation, competitiveness, flexibility, pluralism, performance, and result-orientation (Eikenberry \&Pautz, 2008: 201; Zeren, 2011: 25).

In that scope, the emergence of the NPM is worth to mention, that process can be identified around economic, social, and political factors (Kurt \&Uğurlu, 2007: 83). Within the context of the economic factors, the adoption of the welfare state approach changes the functions of the state, widens the formation of the organization, and leads to the increase at public spending. The economic recession came up in the 1970s and various structural amendments implemented to get rid of from the economic crisis at that related period; and significant steps were taken to reduce the role of the state in the economy (Özer, 2005: 21). The governments launched to implement administrative reforms in order to solve the economic, political, and social problems. As a result of those facts, efficiency and effectiveness concepts came to the front side; the transition of business management techniques and applications to the public administration system had been demanded by the governments (Parlak \&Sobacl, 2005: 203; Sezen, 2006: 42). Moreover, at the evaluation of the social factors, it is seen that the citizens are now more educated, looking for their rights, and they are less obedient to the political authority. Today, people do not only demand more services but also for more qualified service (better quality of service). Lastly, when considering the political factors, it is undeniable that new right ideology affects NPM and creates an ideological basis for it (Bilgiç, 2003: 30-31). According to the new-right thinkers, state's role and intervention should be minimized at the provision of the public services in an effective manner. At that point, new-right thinkers assert that the economic development can be achieved better with this way because the scarce resources used at the most efficient areas in the free-market. Those listed themes came to the front side at the administration system by the effect of all these factors and with the change in the public administration approach, such as;

(1) Public activity fields of state and public employment should be reduced,

(2) Public service delivery should leave to the private sector,

(3) Competitive factors should keep in the forefront at the provision of services,

(4) Limiting the state's legal regulation, restricting and control authority on sectors by deregulation and liberalization (Arap \&YIImaz, 2006: 54).

By the 1980 onwards, 'first generation of structural reforms' or 'economic-financial liberation' wave emerged, with the target of the reduction of the responsibility and functioning area of the state. Economic and political tools of reform are deregulation and privatization (Çetin, 2012: 60). At the neo-liberal political economy, the notion was based on 'minimal state' confined to securing law and order, macro-economic stability, and the provision of physical infrastructure (Öniş \&Şenses, 2003: 1-2). At that context, Turkey has also affected by the neo-liberal policies and significant steps started to be taken at privatization after 1980s. State monopolies in various fields were removed, and the emphasis was given to the deregulation policies (Eryllmaz, 2002: 153). By the 2000s onwards, one of the most serious attempts at public administration launched with the Law No. 5227 on 'Basic Principles and Restructuring of Public Administration' that was prepared with taking into account the themes and principles of NPM. While that Law found no chance for application, the local government laws that put into force one by one complement the local government reform process in accordance with the themes and principles of NPM. In that context, local government laws are significant in indicating the NPM impact at the local administrative system in Turkey. The main objective of that study is the analysis of the basic components of the NPM at the general justifications of the local government laws in Turkey. In that framework, the basic components of the NPM have been searched by the content analysis method at the general justification of the local government Laws No. 5393 on Municipality, Law No. 5216 on Metropolitan Municipality, Law No. 5302 on Special Provincial Administration, Law No. 6360 on The Establishment of Fourteen Metropolitan Municipalities and Twenty-seven Districts and Amendments at Certain Law and Decree Laws. In that framework, before passing to the examination of the justifications of the local laws; the other objectives of the study are the searching of the emergence of NPM at the global planet and in Turkey, and putting forth the key themes, initiatives, and principles of NPM in detail. At that framework, the content analysis method is used in the evaluation of the NPM themes and principles at the general justification of the local government laws. In this regard, content analysis is referred as a flexible method at the analysis of the text data (Cavanagh, 1997). It is an appropriate method for that study because it corresponds with the three fundamental principles of scientific method such as objectivity, systematic, and generalizability. By the objectivity principle the analysis can be carried out on the grounds of explicit rules that allow different researchers to achieve the same results from the same documents; it gives the possibility of making the inclusion of exclusion of the content as to some consistently applied rules; and lastly, the outcomes of the research can be adapted to the other similar studies on that field of study (Prasad, 2008: 3). 


\section{The New Public Management Approach}

A new dimension articulated in the discussions of the public administration and management by the emergence of 'public management approach'. The emergence of that approach within the public administration theory went back to the end of the 1970s and the beginning of the 1980s. In that regard, James Perry and Kenneth Kraemer from the California University in U.S. proclaimed the birth of a new public management science in their published book titled 'Public Management: Public and Private Perspectives' in 1983. Those scholars determined the purpose and characteristics of this new science as follows: 1) To understand and develop the ways, and the methods of the public organizations at their fulfillment of their assigned duties, 2) In doing so, taking the executive power, and its components as the basic unit of analysis, 3) To develop effective tools, and techniques to make the public managers more competent, 4) To focus on comparative techniques between inter-organizations and sections (Üstüner, 2012: 388; Perry \&Kraemer, 1983). The problems that emerged at the legitimization efforts at the theoretical level of public management led to the entrance of that approach to an intellectual crisis in the late 1980s. At that point, Üstüner (2012: 392) clarified that the most significant reason of this crisis stemmed from its limited and reductionist methodology and it made the new expansions necessary. The scholar also put forth that the redefinition of the public management process has been realized with the birth of the new public management.

In the light of those clarifications, NPM launched to be used firstly at the OECD Reports. In that framework, one of the most prominent scholars that used that term is Christopher Hood from London University. Hood's article of 'A Public Management for All Seasons' has a crucial role in the determination of the key aspects of NPM. As to the scholar, "NPM offers an all-purpose key to better provision of public services" linking with 'mega-trends' of administration namely;

i) Attempts to slow down or reverse government growth in terms of overt public spending and staffing,

ii) The shift toward privatization and quasi-privatization and away from core government institutions, with renewed emphasis on subsidiarity in service provision,

iii) The development of automation, particularly in information technology, in the production and distribution of public services,

iv) The development of a more international agenda, increasingly focused on general issues of public management, policy design, decision styles and intergovernmental cooperation on top of the older tradition of individual country specialization in public administration (Hood, 1991:3).

At that framework, the approach that is typically called NPM came to the agenda by different names with various scientists such as 'New Public Management' (Hood, 1991), 'Reinventing Government' (Osborne \&Gaebler, 1993), 'Market-Based Public Administration' (Lan \& Rosenbloom, 1992; Donahue \&Nye, 2002), 'Managerialism' (Pollitt, 1990). In this regard, Pollitt and Dan (2011:4) clarified that NPM origins are strongly connected with the UK Prime Minister Thatcher, and US President Ronald Reagan, and with the New Zealand Labour government of 1984. At that point, Hughes (2003) clarifications are worth to mention, the scholar clarified that 'the NPM movement can be summarized as containing two central arguments: 1) the market, not the government, is the best allocator of resources; and 2) individuals are the best judges of their own welfare. In that scope, the doctrinal components of NPM have been determined by Hood (1991:4-5) as follows:

\begin{tabular}{|c|c|}
\hline $\begin{array}{l}\text { 'Hands-on professional management' in the } \\
\text { public sector }\end{array}$ & $\begin{array}{l}\text { Active, visible. discretionary control of organizations from named persons at the top, } \\
\text { 'free to manage' }\end{array}$ \\
\hline $\begin{array}{l}\text { Explicit standards and measures of } \\
\text { performance }\end{array}$ & $\begin{array}{l}\text { Definition of goals. targets, indicators of success, preferably expressed in } \\
\text { quantitative terms, especially for professional services (cf. Day and Klein 1987; } \\
\text { Carter 1989) }\end{array}$ \\
\hline Greater emphasis on output controls & $\begin{array}{l}\text { Resource allocations and rewards linked to measured performance, breakup of } \\
\text { decentralized bureaucracy wide personel management }\end{array}$ \\
\hline $\begin{array}{l}\text { Shift to disaggregation of units in the public } \\
\text { Sector }\end{array}$ & $\begin{array}{l}\text { Break up of formerly 'monolithic' units. unbundling of U-form management systems } \\
\text { into corporatized units around products, operating on decentralized 'one-line' } \\
\text { budgets and dealing with one another on an 'armslength' basis }\end{array}$ \\
\hline Shift to greater competition in public sector & Move to term contracts and public tendering procedures \\
\hline $\begin{array}{l}\text { Stress on private sector styles of management } \\
\text { practice }\end{array}$ & $\begin{array}{l}\text { Move away from military-style 'public service ethic', greater flexibility in hiring cind } \\
\text { rewards; greater use of PR techniques }\end{array}$ \\
\hline $\begin{array}{l}\text { Stress on greater discipline and parsimony in } \\
\text { resource use }\end{array}$ & $\begin{array}{l}\text { Cutting direct costs. Raising labour discipline. } \\
\text { Resisting union demands. limiting 'compliance costs' to business }\end{array}$ \\
\hline
\end{tabular}


Likewise, Osborne and Gaebler (1992) even called for a cultural shift away from the bureaucratic government towards an entrepreneurial government as it is both competitive and customer- driven. In their study of 'Reinventing Government: How the Entrepreneurial Spirit is Transforming the Public Sector'; those scholars also described the main initiatives and principles of NPM, as follows: Catalytic government: steering rather than rowing; Community-owned government: empowering rather than serving; Competitive government: injecting competition in service delivery; Mission-driven government: transforming rule-driven organizations; Results-oriented government: funding outcomes, not inputs; Customer-driven government: meeting the needs of the customer, not the bureaucracy; Enterprising government: earning rather than spending; Anticipatory government: prevention rather than cure; Decentralized government: from hierarchy to participation and teamwork. Moreover, in addition to the study of Osborne and Gaebler, eight key characteristics that shed light on the character and value emphasis of the techniques and practices of NPM described by Pollitt $(2001,2003$ : 27) as follows:

1. A shift in the focus of management systems and efforts from inputs (and processes towards outputs and outcomes).

2. A shift towards more measurement and quantification, especially in the form of systems of performance indicators and/or explicit standards.

3. A preference for more specialized, lean, flat and autonomous organizational forms rather than large, multipurpose, hierarchical ministries or departments.

4. A widespread substitution of contracts (or contract-like relationships) for what was previously formal, hierarchical relationships.

5. A wide deployment of market mechanisms for the delivery of public services.

6. An emphasis on service quality and a customer orientation.

7. A broadening and blurring of the frontiers between the public sector and the market sector and the voluntary sector.

8. A shift in value priorities away from universalism, equity, security, and resilience and towards efficiency, and individualism.

In this regard, Hood (1991: 5) also clarified that the origins of NPM is a marriage of two streams of approaches. One of them is the 'new institutional economics'. That movement provided the generation of a set of administrative reform doctrines founded on contestability, user choice, transparency, accountability, competition, user preferences, openness and close concentration on incentive structures (Dunsire, 1995: 29; Hood, 1991: 5). The other partner is the 'business type managerialism' in the public sector that was based on the ideas of professional management expertise. At all things considered; it is seen that NPM is composed of the combination of strategies and techniques of market and that approach has the target to combine the political context of public bureaucracies to institutional arrangements. According to that approach, competition between the public, private, and non-profit institutions enables the efficiency, performance, costeffectiveness, and customer satisfaction in the provision of public goods and services (Killian, 2008: 50).

\section{The Emergence of NPM in Turkey}

Turkey does not have a good reputation concerning the reform applications in public administration. At that context, Kapucu and Palabıyık (2008: 194-195) clarified that there are many factors related to the negative results of the restructuring initiatives until the end of 1990s. The scholars determined that the reforms were prepared by a closed and Weberian, hierarchic administration understanding of the industry age. Moreover, other reasons behind the negative outcomes were listed as lack of any serious theoretical foundation underpinning an approach to reform, lack of holistic approaches, and the consideration of public administration system apart from social, economic, political, and cultural systems surrounding it. After the transition of the modern bureaucratic administration approach, many reform initiatives were launched but they remained at report level and found no chance for application. At that framework, the planned period was critical at the administrative reform efforts that had been carried out by the Turkish experts in Turkey. Certain tasks related to the restructuring of public administration were given to the State Planning Organization (SPO) founded in 1960 and the restructuring initiatives reached a legal basis (Coşkun, 2005: 17). One of the first extensive researches at the planned period was 'Central Government Organization Project' (MEHTAP) in 1963 (Tortop et al., 2007: 466). The Project started in 1962 for the determination of the distribution of responsibilities in the ministries, departments, and institutions within the central government organization, and examination of that distribution whether it provides the possibility of efficient realization of public services. The MEHTAP Report has been prepared to allow the central government organization to provide the public services in an effective and efficient way (Leblebici, 2005: 7-8). By Decree No. 7/2527 on 29/05/1971, an 'Administrative Reform Advisory Board' established to designate the general direction of 
the re-organization of the state and the strategy (Sürgit, 1972: 149). In that scope, Administrative Reform Advisory Board was responsible for those listed tasks; determining the general direction and strategy of the restructuring of administration, putting forth the organizational structure that carry out the restructuring process, identifying the areas of restructuring and priorities, evaluating the administrative reforms up to that time and connected it to the application program, ensuring the consistency between state economic enterprise restructuring affairs and the studies in the field of general administration (İdari Reform Danışma Kurulu Raporu, 1972: 1). At that framework, the most comprehensive reform initiative before the new management approach was 'Public Administration Research Project' (KAYA). The main purposes of the Project can be listed as follows; reaching of the central and local organizations of central government and local governments to the efficient, rapid, economic, effective and qualified service provision standards; ensuring compliance of public administration to the developing contemporary conditions, identifying the deficiencies at the public institutions targets, responsibility, authority, at their organizational formation, personnel system, communication and public relation system (Aslaner, 2006).

The paradigm shift that began in the 1980s was also reflected in Turkey. By the 1980s onwards, the privatization initiatives towards the downsizing of the public field are noteworthy at the reflection of NPM. With the Özal period, it was observed that liberalization initiatives were launched. At that related period, first-wave reform process changes occurred in the field of economic management. In addition to the privatization initiatives, state monopolies in various fields were removed and the emphasis was given to the deregulation policies (Eryllmaz, 2002: 153). By the 2000s onwards, the first serious attempt at the public administration in the period began with the Law No. 5227 on 'Basic Principles and Restructuring of Public Administration'. That related Law was fully prepared in accordance with the NPM approach (Güler, 2005). The Law attempted to apply the basic principles of NPM (Kapucu \&Palabıyık, 2008: 196). In that regard, the purposes of this law can be listed as follows; the formation of a public administration based on participation, transparency, accountability, human rights and freedoms; the determination of the authority and responsibilities of central government and local governments for the provision of public services in a just, rapid, qualified, efficient, and effective manner; the restructuring of the central government, and regulation of the basic principles and procedures concerning public services (YIImaz, 2014: 16). In the presence of all these considerations, by the Law on Basic Principles and Restructuring of Public Administration, Yılmaz (2014: 23) emphasized that a serious step has been taken concerning transition of the state's and public administration's power, resource, and responsibilities to the market, local governments, to the civil society. In that scope, while the Law text was not adopted ${ }^{1}$ that formed the legal framework of the reform of public administration, the Law of Public Finance Management, Metropolitan Municipality Law and Special Provincial Law that complement the reform process entered into force by one by in Turkey (Kapucu \&Palabıyık, 2008: 195-196). Finally, it is seen that the new management approach reflected to the municipality and SPA Laws in Turkey (Al, 2008: 27).

\section{The Examination of NPM in Local Government Laws in Turkey}

The main themes and principles of NPM can be listed as customer-orientation, competitiveness, competition in public sector, competitive government, flexibility, pluralism, performance and result-orientation, decentralization, horizontal organization, participation, private sector styles of management practice, service quality, efficiency and effectiveness, subsidiarity in service provision. Within the scope of that study, one of the main objectives is the analysis of those listed themes and principles at the general justifications of the local government laws in Turkey. The general justifications of four local governments Laws' are examined in detail such as Special Provincial Administration Law No. 5302, Municipality Law No. 5393, and Metropolitan Municipality Law No. 5216 and Law No. 6360 on 'The Establishment of Fourteen Metropolitan Municipalities and Twenty-seven Districts and Amendments at Certain Law and Decree Laws'.

\subsection{The General Justification of Special Provincial Administration Law No. 5302:}

At the general justification of the Law No. 5302, it is stressed that the individuals' request has shown a steady increase in related with the participation to the local decision-making process with the augmentation and diversification of the local citizens' demands and rights. It is also pointed out that the wave concerning participation to government right demands that lead to the erosion of the nation-states in the globalized world and strengthening of the decentralized formations felt its existence in Turkey as well as in all countries. Besides, it is clarified that the Republic of Turkey confronted with those

\footnotetext{
1 That reference Law was passed by Turkish Grand National Assembly (TGNA) on July, 2004, however, on August 3, 2004 President Ahmet Necdet Sezer vetoed the law and sent back to TGNA with the reason that the law was not compatible with the general principles of law, the Constitution, and the common interest of the public.
} 
kinds of demands by the 1980s onwards that decentralization launched to be dominant in the administrative system. Therefore, the decentralization and public participation to the administration as a collective subject have been demonstrated at the general justification of the Law as an inevitable necessity. In this context, democracy is determined as a form of administration, and decentralization is highlighted as the guarantee of democracy. As it is seen at the general justification of SPA Law No. 5302; social factors that lead to the emergence of the NPM have been determined specifically with the rising participation demands of the citizens to the local-decision-making process. Besides, decentralization, which is identified as the guarantee of democracy, and public participation entailment have been determined in an explicit way, that are appropriate with the initiatives and principles of NPM such as 'decentralized government: from hierarchy to participation and teamwork'. ${ }^{2}$

\subsection{The General Justification of Municipality Law No. 5393:}

At the general justification of the Law, it was elucidated that a rapid change and transformation have been living that deeply affecting the social formation relations at all over the world. It is also emphasized that the transformation process began at the last quarter of $20^{\text {th }}$ century and continued in the $21^{\text {th }}$ century; with leaving deep impacts on the idea, formation, and functions of public administration and led to the disputes at the responsibilities and working methods. At the general justification of the Law, it was put forward that those discussions that led to the redefinition of the role of the government brought together the demands of the democratization of the public administration. At that context, it was mentioned that the traditional (classical) representation method is inefficient and the principles of openness, participation, responsibility and accountability in service provision should be realized to reach a more democratic public administration and those principles are declared as the essential elements of the public administration. As it is seen from the general justification of the Law, NPM principles and components such as openness, participation, and accountability in service provision have been counted as the essential elements of public administration at reaching to a democratic public administration. Moreover, it is noticeable that NPM is highlighted as a new paradigm that was based on effectiveness and efficiency in administration. Essential necessities in adapting change are counted as being ready to the uncertainties of the future, rapid decision-making, and finding quickly appropriate solutions to the problems. Besides, a transformation and change at the local governments have been declared as a necessity at the restructuring of public administration. In that framework, it is also pointed out that the organizational structure, duties and powers, processes, and targets of the local governments will also subject to change. By the same token, the removal of the excessive bureaucratic formation, the formation of more flexible and smaller units, and questioning of the working method and processes have been indicated as the necessities at the restructuring of public administration. At the general justification, it is elucidated that the public administration system should be restructured and transformed around the effectiveness, efficiency, flexibility, rapid decision-making principles of NPM. From the above clarification, it is also obvious that Hood's doctrinal components of NPM are also demonstrated and used such as the disaggregation of units in the public sectors with the formation of smaller units; and, the other doctrinal component comes to the front side such as private sector style of management by the questioning of the working method and processes of public administration. Furthermore, at the general justification of the Law, it was also illuminated that the prominence of the strategic management in addition to flexible and horizontal organization and emphasis on the entailment of entrepreneurial and competitive characteristics of the government are also compatible conditions with decentralization. The key features of NPM such as entrepreneurial government (earning rather than spending), competitive government (injecting competition), strategic management (explicit standards and measures of performance), flexible and horizontal organization model (a preference for more specialized, lean, flat and autonomous organizational forms rather than large, multi-purpose, hierarchical ministries and departments), decentralization are used specifically at the general justification of the Law No. 5393. Besides, it was also illuminated that assigning more tasks and responsibilities to the local governments at the provision of the public services requires the change of the traditional structure of the allocation of the powers and resources between the central government and local governments. Therefore, it was underlined that the supporting of the local government with more authority, responsibility, and financial resources require corresponding changes in the administrative formation and approach of those administrations. By the assignment of more tasks and responsibilities to the local governments at the public service provision and supporting of the local government with more authority, responsibility and financial resources are the key determinants and indicators towards the decentralization and service quality component of NPM. In the light of those clarifications, it is observed that local governments are declared as the administrative formations that requiring an administrative change compatible with the key themes and principles of NPM. At the general justification of the Law, it

2 For details, see, The general justification of Law No. 5302, <http://www2.tbmm.gov.tr/d24/2/2-0627.pdf>, (10.09.2014). 
was pointed out that an approach that is based on demands of citizens should be ensured in the administrative system to increase the satisfaction of the facilitators and to provide the quality, legality, effectiveness, and efficiency. It is also emphasized that there is the need of mechanisms involving accountability, openness, transparency, predictability at a result-oriented administration. The new paradigm of NPM has been supported by stressing on the entailment of a resultoriented, accountable, effective, efficient, open and transparent administrative system.

Furthermore, local governments are denoted as the guarantee of the local public interests at the representative democracy. On the other hand, it was also underlined that local governments have influential roles as an important element of the democratic system, at the provision of the pluralism and participation, at the reconciliation of local and national interests, at reflection of the public preferences, demands, and expectations to the local-administration. Furthermore, it was stressed that local governments have more possibilities and capabilities in comparison to the central government in related with the provision of the public participation; thus, local governments have been determined as an administrative system that strengthen the administrative capacity of the entire system. At the general justification of the Law No. 5393; it was stressed that as a result of these considerations, the basic values of local governments such as democracy, autonomy, participation, and effectiveness principles tried to be reflected to the ground of the Law. The autonomy which is the prerequisite of the principle of decentralization has been highlighted at the justification of the Law such as; the duties and services that are assigned to the local government by laws should be realized by the decisions of their bodies and under their responsibility. Besides, the components of NPM such as effectiveness, efficiency, and participation have been identified in a clear way, and those themes are determined as the elements of the new administration system. It was also stressed that some of the provisions that are brought by the reference Law at the restructuring of the municipalities are relevant with the more democratic, participatory, and transparent administrations; it was underlined that there is a close relationship with the local citizens' demands for participation to local-decision making process and efficient provision of public services. As it was seen from the above clarifications, the justification of the Law also tries to set up a bridge between NPM and municipal administration with the NPM's key themes of democracy, participation, and transparency.

One of the new arrangements in related with participation is determined as the participation to the municipal councils and specialized commissions; and submission of opinions to those local mechanisms. By those new arrangements; it was stressed that municipal council decisions will be announced to the public with the most appropriate way. The city councils are identified as a platform where everyone reaches the opportunity to explain their opinions with the support of the municipality. It was also added that the foresight of the evaluation of the council decisions at the first meeting of the municipal council will form another dimension to participate to the municipal administration. It is seen that significant steps have been put forward at the general justification of the Law in terms of the public participation which is one of the main components of NPM.

Furthermore, another objective envisaged by the justification of the Law is determined as the establishment of an effective and efficient administration at the municipalities. It is pointed out that the municipalities will prepare their fiveyear strategic plan that involves the basic targets and the activities that are carried out to reach the determined targets. At that point, it is also added that the annual working program, budgets, and performance criteria have been formed according to this plan. It is asserted that the municipalities will form future-oriented policies that bring long-term solutions and have a result-oriented approach with those five-year strategic plans. As it was seen from the clarifications, strategic management, efficiency, effectiveness, and result-oriented approach themes of the NPM are determined as the objectives of that justification of the Law. It was also determined that the municipal council reach the authority to decide on granting of franchise on behalf of municipality, realization of investments by the municipality on built-operate or builtoperate-transfer basis; privatization of the companies, enterprises, and participations of the municipality. By those alternative service provision methods, it was pointed out that the working methods will be varied, and it will contribute to the provision of the effectiveness. As it was declared at the determination of NPM, that new paradigm tried to set up close relation with private sector and public administration with the objective of benefiting from the private sector management practices which can be also explained as a wide deployment of the market mechanism at the delivery of the services. At the above clarification, those private sector practices and working methods are supported in the effective provision of public services at the municipal administration. The other provisions that are brought by the justification of the Law are determined as, the foresight of an employment policy compatible with the performance evaluation and strategic management, and giving possibility to the flexible organization for the establishment of an effective management at the municipal administrations. As it was declared before, the justification of the Law submitted the key components of NPM at 
its provisions such as performance evaluation, strategic management, and flexible administration 3 .

\subsection{The General Justification of Metropolitan Municipality Law No. 5216:}

At the beginning of the general justifications of the Metropolitan Municipality Law No. 5216, it was expressed that at a system which is started to be implemented for the first time in 1984 with the Law No. 3030 which has no previous experience, has naturally some shortcomings in its application process. The accepted problems at that framework clarified as follows; there is no objective criteria at the sharing of responsibility and functions, the cooperation mechanisms are insufficient among the administrative mechanisms, the metropolitan municipal administration has a definite hegemony on district, and first-tier municipalities, planning and coordination at the metropolitan scale cannot be done at the metropolitan level and the size of the municipalities are very different. Those problems listed above were asserted as the source of the inefficient and ineffective usage of resources.

At the general justification, it was declared that the concentration of population in relatively several cities of the country leads to the emergence of huge centers. It was also pointed out that these centers have faced with not only inadequate services but also a serious of problems that are stemmed from their size. Additionally, as to the government, most of the local government units that set up in the metropolitan urban areas have also lack of capacity to solve the problems that they encounter handicaps owing to their organizational structure, insufficiency of their service provision capabilities, and financial resources. At that point, according to the government, there are mismatches at the local service provision, and those factors are assumed to eliminate the effectiveness and efficiency at local administration process. It is mentioned that a large number of local government units have the responsibility at the provision of the local services that inconsistencies emerged in the planning and coordination, and it is not benefited from the economies of scale; resources are wasted as a result of this plight.

At the general justification of the Law No 5216, it was pointed out that to cope with the problems of the metropolitan cities entail the application of different administrative models. The formation of two-tier administrative system application in the large cities is highlighted as a method that gained prevalence in the world. Also, it is determined that in our country a variety of researches and studies have been made, and draft laws have been prepared concerning the establishment of different administrative formations in the metropolitan areas. It was also expressed that special administrative formations entailment has been determined at the Five-Year Development Plans and the restructuring public administration reports especially for Istanbul and other big cities. At that point, at the general justification of the Law, it was pointed out that to solve those listed problems and to make the effective functioning of the metropolitan municipal administration emerged as an urgent need. On the other hand, the developments in the public administration entail the restructuring of the metropolitan municipalities and reaching them to an effective, transparent, accountable and participatory formation. As it is seen from the clarifications, the themes and principles of NPM are observed at the restructuring of metropolitan administrations to reach and adapt the developments of public administration.

By the general justification, those listed issues are arranged such as; the establishment of metropolitan, district, and first tier municipalities, their organs, responsibilities, powers, income, organizations and the relation between the municipalities. Besides, at the division of the tasks, it is determined that the local common tasks and services that their impacts do not surpass the municipal borders and also which can be done within the district and first tier municipal borders should be fulfilled by the district and first-tier municipalities. At that framework, the tasks and responsibilities that are entailed for planning and coordination at the metropolitan-wide or which are required to be done in financial terms by metropolitan municipality will be fulfilled by the metropolitan municipality. In that context, it was pointed out that the services which can be done by the district and first-tier municipalities but can lead to challenges in the application process will be fulfilled by the metropolitan municipality. Such a division of task assumed to provide objectivity in the application process and also it is supposed to give the possibility of realization of the subsidiarity principle at services among the administration levels. At that point, it is explicit that, the task distribution is planning to be made concerning the decentralization and the principle of subsidiarity which are the main themes of the new paradigm of NPM. It was assumed that by the legalization of that general justification; the problems that the metropolitan municipalities encounter will be solved rapidly and the services will be provided in an effective and efficient way. Consequently, it is seen that the themes of NPM such as effectiveness and efficiency at the service provision are tried to be integrated with the Law No. $5216^{4}$.

${ }^{3}$ For Details, see, The general justification of Law No. 5393, < http://www.sayilikanun.com/5393-sayili-belediye-kanununun-gerekcesi/> (05.12.2014).

${ }_{4}^{4}$ For Details, see, The general justification of Law No. 5216,< http://www.sayilikanun.com/5216-sayili-buyuksehir-belediyelerikanununun-gerekcesi> (05.12.2014). 


\subsection{The General Justification of the Law No. 6360 on the Establishment of Fourteen Metropolitan Municipalities and Twenty-seven Districts and Amendments at Certain Law and Decree Laws:}

According to the general justification of the Law No. 6360, similar with the Law No. 5216, it was expressed that the administration approach has changed with globalization, and new values have been emerged with this transition. It was also underlined that the administration approach that is effective, efficient, citizen-focused, accountable, transparent, participatory, and local comes to the front side as the basic principle for the public administration reforms in many developed countries. As it is seen from the above clarification new themes of NPM such as effectiveness, efficiency, citizen-orientation, accountability, transparency, participation, and decentralization started to be used as the entailments of the public administration reforms. Those principles and values envisaged not only the development of the service quality with the target of increasing the citizens' satisfaction but also the provision of more participation of local citizens to the public administration. At the general justification of the Law, it was also stressed that the public administration has to meet the effectiveness, efficiency, and local citizens' service expectations at that new approach. It is observed that it is tried to set up a bridge between the NPM and its new values with the public administration.

Moreover, local governments are determined with the aspect of the local citizens' participation to the democratic life. Therefore, it was highlighted that the local governments should constantly be developed and reached the effective service provision capacity. At the general justification of the Law, it was emphasized that while the local governments within the metropolitan cities borders can make small-scale plans; those plans are required to deal with in a broad framework that determine the macro policies and with an integrated approach that including the metropolitan region. One of the other reasons at the requirement of the metropolitan municipality is expressed as not the provision of the planning and coordination with the large number of local governments' authorization at a specific geographic area, and the poorly utilization from the economy of scale that leading to the waste of resources. In that context, it is determined that the small scale local governments having inadequate financial resources, and incapacities at service provision cannot solve the problems stemmed from industrialization, transportation, and environment. It was declared that this situation prevents the effective and appropriate usage of resources and leads to serious administrative problems not only at small settlements, but also at big cities having a dense population. In that scope, lacking of the strong local government that will produce effective local services asserted to lead to the emergence of the problems such as not meeting the hopes of the local citizens concerning the provision of qualified public services, and lacking of coordination at the delivery of the public services.

In this context, at the general justification of the Law, it was determined that the existence of strong local administrative formations that can produce services in optimal scale is entailed in terms of administration, planning, and coordination. At that point, it is pointed out that the effectiveness, coordination, and quality will rise by the economies of scale that emerges as a result of execution of the provided services at the metropolitan area; qualified service provision can be ensured with fewer resources. The provision of services, by a big center having an ideal scale that are currently provided by more than one center lead to the reduction of the unit costs and per capita public expenditure. It is perceived that when the metropolitan municipality borders are expanded to the provincial borders, it is hoped to reduce the public expenditure at the service provision which is one of the key components of NPM. From this point of evaluation, the metropolitan municipality model that will provide services at the provincial border is assumed to reveal those following positive developments as follows:

- Local government units that produce broad-scale services can be equipped with advanced technologies.

- At those units, qualified technical staff can be employed, and also the productivity will be increased as to the specialization of the labor power.

- The local government system that is formed from broad-scale local units can provide efficient use of resources that will be transferred from the center.

- A more equitable formation will come out from the aspect of the facilities to be owned and the usage of the resources among the local government units that are integrated within the provincial borders.

Finally, it can be clearly stated that with the Law No. 6360, the effectiveness and efficiency themes of NPM have been integrated to the local public service provision process of metropolitan municipalities. Metropolitan municipality is asserted as the administrative unit having the required potential at the efficient usage of resources, at the preparation of integrated development plan, at the augmentation of the productivity as to the specialization of the labor power 5 .

\footnotetext{
${ }^{5}$ For details, see, The general justification of Law No. 6360, <http://www2.tbmm.gov.tr/d24/2/2-1316.pdf>, (09.11.2014).
} 


\section{Conclusion}

By the 1980s onwards, the management of public sector has witnessed a significant transformation in many developed countries, with the emergence of the new paradigm of NPM. At that framework, NPM came out as a challenge to the classical public administration. In that regard, most of the advocates of the NPM emphasize the negative sides of the public organizations and institutions with indicating their Weberian peculiarities of hierarchy, division of labor, and too much dependence on formal norms (Killian, 2008: 50). Therefore, new themes and principles of the public sector can be listed as follows; customer-orientation, flexibility, pluralism, performance and result-orientation, decentralization, horizontal organization, competition in public sector, competitive government, participation, private sector styles of management practice, service quality, efficiency and effectiveness, subsidiarity in service provision. In that context, by the 2000s onwards, especially with the Law No. 5227 on 'Basic Principles and Restructuring of Public Administration', serious steps have been taken concerning the transition to the principles of NPM in Turkey. The Law attempted to apply the basic principles of NPM (Kapucu \&Palabıyık, 2008: 196). While that Law text was not adopted, the local government laws that complement the reform process entered into force by one by in Turkey. In that context, the general justifications of four local governments Laws' are examined in detail such as Special Provincial Administration Law No. 5302, Municipality Law No. 5393, and Metropolitan Municipality Law No. 5216 and Law No. 6360 on 'The Establishment of Fourteen Metropolitan Municipalities and Twenty-seven Districts and Amendments at Certain Law and Decree Laws' in terms of the principles and themes of the NPM. In almost at all of the general justification of the examined laws, it is seen that the principles of participation, effectiveness, efficiency, accountability, transparency, decentralization, subsidiarity, private sector based method applications at public sector, horizontal organization, performance management and result orientation, strategic planning, competitiveness, flexibility, pluralism, service quality, cost-efficiency, openness, economy of scale principles of NPM came to the front side. A transformation necessity in the public administration system has been highlighted at all local laws to reach the success at the administrative system with the above listed NPM principles. Moreover, the reduction of cost/ cost efficiency principle tried to be reached by the application of private sector methods to public sector and with facilitating from the economy of scale by enlarging the scale. In that context, the effectiveness and efficiency at service provision principles tried to be ensured by horizontal and flexible organization model, performance management, accountability, transparency, citizen-orientation, and public participation. Moreover, decentralization principle which is declared as the guarantee of democracy tried to be reached by assigning more tasks and responsibilities to the local governments and supporting of the local governments with more financial resources. Lastly, participation principle tried to be reached by the new participatory platforms such as city councils. Consequently, it is obviously seen that public administration system tried to be restructured and transformed around the effectiveness, efficiency, openness, participation, accountability, transparency, subsidiarity, flexibility, performance management, costefficiency, private sector based method applications and rapid decision-making principles of NPM and those principles have been counted as the essential elements of public administration at reaching to a democratic public administration system in Turkey.

Table 1: The Key Principles of NPM at the General Justifications of the Local Government Laws in Turkey:

\begin{tabular}{|c|c|c|c|c|}
\hline & The Law No. 5302 & The Law No. 5393 & The Law No. 5216 & The Law No. 6360 \\
\hline Participation & $\sqrt{ }$ & $\sqrt{ }$ & $\sqrt{ }$ & $\sqrt{ }$ \\
\hline Decentralization & $\sqrt{ }$ & $\sqrt{ }$ & $\sqrt{ }$ & $\sqrt{ }$ \\
\hline \multicolumn{5}{|l|}{ Customer-orientation } \\
\hline Competitiveness, competition in public sector & & $\sqrt{ }$ & & \\
\hline Flexibility and rapid decision-making & & $\sqrt{ }$ & $\sqrt{ }$ & \\
\hline Pluralism & & $\sqrt{ }$ & & \\
\hline Performance and result-orientation & & $\sqrt{ }$ & & \\
\hline Horizontal organization & & $\sqrt{ }$ & & \\
\hline Private sector styles of management practice & & $\sqrt{ }$ & & \\
\hline Service quality & & $\sqrt{ }$ & & $\sqrt{ }$ \\
\hline Efficiency and effectiveness & & $\sqrt{ }$ & $\sqrt{ }$ & $\sqrt{ }$ \\
\hline Cost efficiency/ reduction of cost & & & & $\sqrt{ }$ \\
\hline Subsidiarity & & & $\sqrt{ }$ & \\
\hline Democratization of the public administration & & $\sqrt{ }$ & & \\
\hline Openness & & $\sqrt{ }$ & & \\
\hline Accountability & & $\sqrt{ }$ & $\sqrt{ }$ & $\sqrt{ }$ \\
\hline
\end{tabular}




\begin{tabular}{|l|c|c|c|c|}
\hline Transparency & & $\sqrt{ }$ & $\sqrt{ }$ & $\sqrt{ }$ \\
\hline Strategic management & & $\sqrt{ }$ & & \\
\hline Entrepreneurial government & & $\sqrt{ }$ & & \\
\hline Competitive government & & $\sqrt{ }$ & & \\
\hline Economy of scale & & & $\sqrt{ }$ & $\sqrt{ }$ \\
\hline
\end{tabular}

\section{References}

Al, H. (2008). Yeni kamu yönetimi: ülke deneyimleri, İstanbul: Değişim Yayınları.

Arap, İ. \& Yılmaz, L. (2006). Yeni kamu yönetimi anlayışının yeni kurumu: kamu görevlileri etik kurulu, Amme İdaresi Dergisi, Cilt:39, Sayl:2, pp.51-69.

Aslaner, A. (2006). Kamu idaresinde yeniden yapılanma çalışmaları, pp.47-67, http://www.icisleri.gov.tr_icisleri Turk Idare Dergisi>. (04.15.2015).

Bilgiç, V. (2003). Yeni kamu yönetimi anlayışı, (Eds). Asım Balcı, Ahmet Nohutçu, Namık Kemal Öztürk, Bayram Coşkun, Kamu Yönetiminde Çağdaş Yaklaşımlar, Ankara: Seçkin Yayıncılık.

Cavanagh, S. (1997). Content analysis: concepts, methods and applications. Nurse Researcher, 4(3), pp. 5-16.

Coşkun, B. (2005). Türkiye'de kamu yönetiminde yeniden yapılanma tarihsel geçmiş ve genel bir değerlendirme, Türk İdare Dergisi, Sayl: 448, pp.14-47.

Donahue, J.D. \&Nye, J.S. (2002). Market-Based governance: supply side, demand side, upside and downside, Washington: Brookings Institution Press.

Dunleavy, P. \&Hood, C.C. (1994). From old public administration to new public management, Public Money and Management, 14(2), pp.9-16.

Dunsire, A. (1995). Administrative theory in the 1980s: a viewpoint. Public Administration, Vol. 73, pp.17-40.

Eikenberry, A. \&Pautz, M. C. (2008). Administrative reform in the united states: toward government-nonprofit partnerships in governance, (Eds). Jerri Killian and Niklas Eklund, Handbook of 219 Administrative Reform: An International Perspective, CRC Press, New York, pp. 197-213.

Eryılmaz, B. (2002). Bürokrasi ve siyaset: bürokratik devletten etkin yönetime, İstanbul: Alfa Yayınları.

Güler, B.A. (2005). Devlette reform yazıları: dünyada ve türkiye'de ekonomik liberalizasyondan siyasi-idari liberalizasyona, Ankara: Paragraf Yayınları.

Hood, C. (1991). A public management for all seasons, Public Administration, Vol. 69, spring issue, pp.3-19.

Hughes, O. (2003). Public management and administration: an introduction. New York: Palgrave.

İdari Reform Danışma Kurulu Raporu (1972). İdarenin yeniden düzenlenmesi: ilkeler ve öneriler (Ankara: Sevinç Matbaası).

Kapucu, N. \& Palabıyık, H.(2008). Turkish public administration: from tradition to modern age, Ankara: International Strategic Research Organization.

Killian, J. (2008). The missing link in administrative reform: considering culture, handbook of administrative reform: an International perspective, (Eds.) Jerri Killian and Niklas Eklund, Auerbach Publications, Boca Raton.

Kurt, M., \&Uğurlu, Ö.Y. (2007). Yeni kamu yönetimi ve yeni kamu yönetimi yaklaşımının gelişiminde avrupa birliği'nin rolü: ilerleme raporları içerik analizi, Afyon Kocatepe Üniversitesi IiBF Dergisi, Cilt: 9 Sayl: 2, pp.81-109.

Lan, Z. \& Rosenbloom, D.H. (1992). Public administration in transition, Public Administration Review, Vol. 52, No. 6, pp. 535-537.

Leblebici, D.N. (2005). Küresel değişim baskısına karşı Türk bürokrasisindeki yapısal uyum çabalarının yapısal atalet kavramı açısından değerlendirilmesi, Cumhuriyet Üniversitesi Ikttisadi ve İdari Bilimler Fakültesi Dergisi, C:6, pp.1-14.

Osborne, D. \&Gaebler, T. (1992). Reinventing government: how the entrepreneurial spirit is transforming the public sector. Reading, Mass.: Addison-Wesley.

Osborne, D. \&Gaebler, T. (1993). Reinventing government: how the entrepreneurial spirit is transforming the public sector, New York: A Plume Book.

Ömürgönülşen, U. (1997). The new public management, AÜSBF Dergisi, C.52, Ocak-Aralık, No:1-4, pp.517-566.

Önez Çetin, Z. (2012). A critical evaluation of local poverty alleviation policies: the case of three provinces in Turkey, METU, Unpublished Master Thesis.

Öniş, Ziya \&Şenses, F. (2003). Re-thinking the emerging of post-washington consensus: a critical appraisal, ERC Working Paper in Economics 03/09 November 2003, pp. 1-36.

Özer. M.A. (2005). Yeni kamu yönetimi: teoriden uygulamaya, Ankara: Platin Yayınları.

Özer, M.A. (2012). Yeni kamu yönetimi, Ankara: Barı̧ Kitabevi.

Parlak, B., \&Sobacı, Z., (2005). Kuram ve uygulamalarda kamu yönetimi ulusal ve global perspektifler, Istanbul: Aktüel Yayınları.

Perry, J. \&Kraemer, K. (1983). Public management: public and private perspectives, California: Mayfield Publishing Co..

Prasad, D. (2008).Content Analysis A method in Social Science Research1 B p.3, http://www.css.ac.in/download/Content\%20Analysis \%20A\%20method\%20of\%20Social\%20Science\%20Research.pdf (02.01.2015).

Pollitt, C. (1990). Managerialism and the public services: the anglo-american experience, Basil Blackwell, Oxford.

Pollitt, C. (2001). Clarifying convergence: striking similarities and durable differences in public management reform, Public Management, 2(2), pp.181-199.

Pollitt, C. (2003). The essential public manager. Buckingham: Open University Press/McGraw Hill. 
Pollitt, C. \&Dan, S. (2011). The impacts of the new public management in Europe: a meta analysis, cocops work package 1-deliverable 1.1

Promberger, K. \& Rauskala, M. I. (2003). New public management-an introduction from the UK perspective working paper, 6/2003.

Sarker, A. E. \&R. D. Pathak. (2000). New public management: an analytical review, Productivity, Volume 41, Number 1., pp.56-65.

Sezen, S. (2006). Teori ve uygulamada yeni kamu yönetimi, Ankara: Seçkin Yayıncllık.

Sürgit, K. (1972). Türkiye'de idari reform, TODAIE Yayını, Ankara.

Tortop, N., İspir, E.G., Aykaç, B., Yayman, H., Özer, M.A. (2007). Yönetim bilimi, 7. Baskı, Ankara: Nobel Yayınları.

Üstüner, Y. (2012). Türkiye'de kamu yönetimi (Eds.) Burhan Aykaç, Şenol Durgun, Hüseyin Yayman, Kamu yönetimi kuramı ve kamu işletmeciliği okulu, pp.387-404.

Yılmaz, A. (2014). AB'ye uyum sürecinde türk kamu yönetiminin dönüşümü üzerine notlar, Dumlupınar Üniversitesi Dergisi, 17.Sayı, pp.1-26.

Zeren, H.E. (2011). Yeni Kamu yönetimi düşüncesinin Türkiye'de kent yönetimine etkisi, (Eds). Yüksel Koçak, A. Cem Çiçek, Kamu yönetimi: yönetim-siyaset, sorunlar ve yeniden yapılanma, SFS Grup Yayınevi, Ankara, pp. 23-48. 